\title{
Contribution of native forests to climate change mitigation - A common approach to carbon accounting that aligns results from environmental- economic accounting with rules for emissions reduction
}

\author{
H. Keith ${ }^{\mathrm{a}, \mathrm{b}, *}$, M. Vardon $^{\mathrm{a}}$, J.A. Stein ${ }^{\mathrm{a}}$, D. Lindenmayer ${ }^{\mathrm{a}}$ \\ ${ }^{a}$ Fenner School of Environment and Society, The Australian National University, Canberra, 2601, Australia \\ ${ }^{\mathrm{b}}$ Griffith Climate Change Response Program, Griffith University, Queensland, 4222, Australia
}

\section{A R T I C L E I N F O}

\section{Keywords:}

Environmental-economic accounting

Carbon accounting

Climate change mitigation

Carbon storage and sequestration

Forest management

\begin{abstract}
A B S T R A C T
Comprehensive carbon stock and flow accounts integrated with economic information, under an environmentaleconomic accounting framework, provide a common approach for an information system to improve policymaking for climate change mitigation, sustainable development and forest management. The information system includes environmental and economic data, linkages between land use activities, their co-benefits, inputs to the economy and benefits for human well-being. Forest management was used as an example of application of the accounting framework because it has the greatest climate change mitigation potential of all land use activities. A case study developing carbon accounts for a forest region in south-eastern Australia demonstrated the mitigation benefits of long-term carbon storage and sequestration in native forests. Using environmental-economic accounts helped identify policy and market instruments required to value ecosystem services of carbon storage and sequestration by applying a potential market price for carbon. We identified benefits of native forest protection as a carbon abatement activity, and compared this value to that of current forest management for timber harvesting that reduces carbon stocks. Both land uses provided similar economic contributions (approximately $\$ 12$ million $\mathrm{yr}^{-1}$, using a minimal carbon price), but native forest protection has additional co-benefits of improving water yield, tourism, recreation and biodiversity conservation. The accounts determine values of land use activities in physical and monetary metrics, and link these to beneficiaries of ecosystem services, so that maximum benefits for public good are identified. Quantifying ecosystem services of carbon storage (protecting stocks) and sequestration (increasing flows) in a native forest region, by applying a potential market price, broadens the policy options for mitigation activities. Adopting a comprehensive accounting system, and changing some of the definitions and rules under the Paris Agreement and national emissions reduction policies and markets, would allow the mitigation benefit of protecting native forests to be realised.
\end{abstract}

\section{Introduction}

Evaluating changes in stocks and flows of carbon is critical for understanding sustainability of ecosystems, dependency of economic activities on the carbon cycle, and impacts of emissions on the climate. Comprehensive carbon stock and flow accounts integrated with economic information, as described in the System of EnvironmentalEconomic Accounting (SEEA) (UN et al., 2014a,b), provides a common approach for carbon accounting, enhancing the information available for policymaking and public understanding of sustainable development, climate change mitigation and forest management. A case study is used to identify policy options for long-term sequestration and storage of carbon in the land sector (vegetation and soils). Accounting for carbon in ecosystems and the economy allowed an integrated analysis, contributing to current investigations about interactions of climate change with global and national economic policies (McKibbin et al., 2017), thus enabling better decision-making about trade-offs between environmental and economic impacts. The integrated environmental and economic accounts also mean that costs of mitigation and risks associated with climate change can be assessed and spread across society and over time.

Human activities in the land sector are causing changes in the global carbon cycle and hence contributing to climate change. Land use, land use change, and forestry (LULUCF) currently contributes about $10 \%$ of

\footnotetext{
${ }^{*}$ Corresponding author at: Fenner School of Environment and Society, Building 141 Linnaeus Way, The Australian National University, Canberra, 2601, Australia.

E-mail addresses: Heather.Keith@anu.edu.au (H. Keith), Michael.Vardon@anu.edu.au (M. Vardon), John.Stein@anu.edu.au (J.A. Stein), David.Lindenmayer@anu.edu.au (D. Lindenmayer).
} 
global greenhouse gas (GHG) emissions as $\mathrm{CO}_{2}$, and about $25 \%$ including $\mathrm{CH}_{4}$ and $\mathrm{N}_{2} \mathrm{O}$, but $35 \%$ of the total accumulated anthropogenic GHG emissions (Houghton et al., 2015). Approximately 33\% of current anthropogenic emissions are removed by terrestrial ecosystems, mostly forests (Grassi et al., 2017). Including land use in the United Nations Framework Convention on Climate Change (UNFCCC) has been complex and controversial, particularly because of methodological issues. Within the global carbon budget, uncertainty in carbon stocks and flows is highest in the land sector (Friedlingstein et al., 2014). These uncertainties are compounded by conceptual issues with accounting rules, for example, definitions of additionality, leakage, permanence, baselines, and anthropogenic versus non-anthropogenic emissions (Appendix D) (Grassi et al., 2017; Griscom et al., 2009). Projected LULUCF emissions vary greatly depending on policy scenarios and ecological and socio-economic constraints (Grassi et al., 2017). However, countries implementing their Nationally Determined Contributions (NDCs) clearly expect a key contribution from LULUCF, particularly forests. Mitigation potential of the land sector is approximately $25 \%$ of total emission reductions planned in the combined NDCs to 2030 from the Paris Agreement (UN, 2015).

Maintaining terrestrial carbon stocks by reducing losses from land use is critical for climate change mitigation. Achieving this mitigation potential will require reducing uncertainties in data, improving transparency in reporting, and tracking progress toward achieving nations' individual targets. Much work remains in the post-Paris Agreement negotiations to develop and revise methodologies for monitoring and reporting on emissions reduction targets, especially in the land sector. We suggest that expanding the accounting and reporting of carbon stocks and flows in alignment with the SEEA will contribute significantly to achieving the UNFCCC goal of maintaining temperature increases below $2^{\circ} \mathrm{C}$, and even $1.5^{\circ} \mathrm{C}$ (IPCC, 2018). This goal means stabilising atmospheric $\mathrm{CO}_{2}$ concentrations below $450 \mathrm{ppm}$ (requiring a limit of cumulative emissions of $790 \mathrm{Gt} \mathrm{C}_{-}$eq, of which $565 \mathrm{Gt} \mathrm{C}_{-}$eq has been emitted) (Le Quéré et al., 2016; Steffen et al., 2017). Alignment of the reporting under the Paris Agreement with the SEEA will enable improved understanding of comprehensive carbon stock changes and the economic costs and benefits of land use change, which then provide decision makers with more complete information.

SEEA provides internationally standardised guidelines for environmental-economic accounting comparable with the System of National Accounts (SNA) (European Commission et al., 2008) and demonstrates the interrelationships between the environment and the economy. SEEA provides a common information system to support multiple policies and integrated decision-making, and allows monitoring of policy effects over time. Both ecosystem service assessments (Ruckelshaus et al., 2015) and the SEEA (Vardon et al., 2016) help make resource planning more transparent and inclusive, but are underutilised in policy. Applications are emerging, ranging in scale from global climate change mitigation targets under the UNFCCC and Sustainable Development Goals (SDGs) (Goal 13 Climate Action and Goal 15 Life on Land: UNDP, 2015), to national NDC targets, and regional natural resource management planning (Keith et al., 2017, Medrilzam, 2017, Remme et al., 2015). Efficiencies can be achieved by using the same concepts, methodologies and data sources for reporting on all these targets, as well as elucidating interrelationships and common objectives among policies.

The importance of ecosystem services for maintaining sustainable development and human well-being is gaining greater acceptance (Ruijs et al., 2017). However, quantifying ecosystem services in terms of spatial distributions and trade-offs remain challenging (PalaciosAgundez et al., 2015; Spanò et al., 2017). Trade-offs in quantitative spatial and temporal terms are fundamental for natural resource decision-making and understanding these is a major tenet of the Millennium Ecosystem Assessment (MEA, 2005).

This study aimed to demonstrate how synthesising data in environmental-economic accounts could translate scientific and economic information in a policy-relevant manner to inform land management decisions regarding sustainability and climate change mitigation. Our overarching goal was to incorporate this new understanding of carbon accounting within the SEEA into national legal frameworks and UNFCCC international rules for GHG inventory and emissions reduction policies.

Carbon accounting for UNFCCC reporting has concentrated on flows and emissions reduction during the Kyoto Protocol. However, it is recognised now that meeting the Paris Agreement goal of stabilising the atmospheric $\mathrm{CO}_{2}$ concentration to achieve a temperature increase below $2{ }^{\circ} \mathrm{C}$ will require additional $\mathrm{CO}_{2}$ removals, as well as rapid emissions reduction (Gasser et al., 2015). Storage and sequestration of carbon are critical mitigation activities for avoiding emissions and increasing removals of carbon, which also have multiple co-benefits (Erb et al., 2017). Forest management, including avoided harvesting and restoration, provides a useful example of the application of the accounting framework because it has the greatest climate mitigation potential of all land use activities. However, confusion persists about the relative benefits of specific activities to increase sequestration and reduce emissions (Griscom et al., 2017; Hieke et al., 2018). The information presented in accounts can help address this issue.

To investigate the potential for SEEA accounts to inform climate change mitigation policy about magnitudes and uncertainties of carbon stocks and flows under forest management, we used a case study of comprehensive carbon accounts for a forest region in south-eastern Australia. This was part of a larger assessment that examined a range of environmental assets and the services they provide (Keith et al., 2017). Forest management in this region for either wood production or conservation is controversial with respect to their relative climate change mitigation values, as well as other values, and currently is undergoing re-negotiation (Lindenmayer, 2018). Hence, this was a useful case study to examine the benefits of information presented as SEEA accounts to inform this policy question. The specific questions addressed in the case study to elucidate the relative values of different land uses for climate change mitigation included:

(1) What is the current carbon stock in the target region, incorporating environmental variation, land cover and land use, and disturbance history, in a spatial accounting framework?

(2) What is the difference in current carbon stock due to different forest management systems?

(3) What would be the historical difference in carbon stock if forest harvesting had not occurred, calculated using actual data that conform to the accounting approach of retrospective analysis about what has happened?

(4) What would be the projected change in carbon stock comparing future scenarios about what will happen under 'additional activities' required for emissions reduction policy, that is, if current forest harvesting ceased and land management was changed from production to conservation?

(5) What is the economic trade-off between carbon storage for climate change mitigation compared with the timber provisioning service from native forests or plantations?

Our study demonstrated the feasibility and benefits of using environmental-economic accounting. We describe the international policy context of both emissions reduction and environmental-economic accounting to explain the issues and gaps that this study aimed to address, and provide some specific examples from Australia. The Methods and Results sections, and the accompanying detailed Appendices, describe development and analysis of the carbon accounts. Application of accounting and related analyses have general implications as they can be used in any region and any scale. Our SEEA-based evaluation of forest management for carbon storage and sequestration was used to inform decisions about land use. The accounting allowed linkages and feedbacks among activities, their co-benefits, inputs to the economy and 
Table 1

Comparison of existing accounting systems (SNA and NGGI) and proposed carbon stock and flow accounting system.

\begin{tabular}{|c|c|c|c|}
\hline Characteristics & SNA $^{\mathrm{a}}$ & NGGI Australia ${ }^{\mathrm{b}}$ & SEEA Carbon accounts ${ }^{\mathrm{c}}$ \\
\hline Structure & Stocks and flows & Net flows & Stocks and flows \\
\hline Data coverage & Economic activity & Net $\mathrm{CO}_{2}$ emissions & Carbon stocks and stock changes \\
\hline Metrics & Monetary & Physical & Monetary and physical \\
\hline $\begin{array}{l}\text { Geographic } \\
\text { coverage }\end{array}$ & Complete (all institutional units within a country) & $\begin{array}{l}\text { Incomplete (international transport not } \\
\text { included) }\end{array}$ & Potentially complete \\
\hline Spatial units & Categories by activity and State & Categories by land use & Spatial \\
\hline Time scale & Annual and continuous & Reporting by commitment periods & Potentially annual and continuous \\
\hline Activity coverage & All economic activities & $\begin{array}{l}\text { Net anthropogenic GHG emissions from } \\
\text { 'managed lands' for UNFCCC. Kyoto } \\
\text { inventories are for elected lands and activities. }\end{array}$ & All carbon stocks and stock changes \\
\hline $\begin{array}{l}\text { Sectors and } \\
\text { categories }\end{array}$ & $\begin{array}{l}\text { Standard International Industry Classification (e.g. } \\
\text { agriculture, mining, energy) and sectors (e.g. public, } \\
\text { private, not-for-profit) of all economic activities }\end{array}$ & $\begin{array}{l}\text { Activity classification of GHG emissions but } \\
\text { need to demonstrate additionality of activity }\end{array}$ & $\begin{array}{l}\text { Industry and sector classification as per SNA } \\
\text { Classification of land units by reservoirs } \\
\text { (geocarbon, biocarbon, anthropogenic reservoirs) }\end{array}$ \\
\hline
\end{tabular}

a European Commission et al. (2008).

b IPCC (2014); DoEE (2015).

c UN et al. (2014a,b).

benefits for human well-being to be included in the information system. Trade-offs were revealed between land uses in achieving optimum mitigation benefits by maximizing carbon stocks. In the Discussion, we highlight opportunities for a common approach to carbon accounting to meet a range of policy needs by improving accounting methodologies in the SEEA. The results demonstrate the potential for analysing environmental-economic trade-offs and we make recommendations about policy and market instruments required to realise the climate change mitigation potential of forest management.

\section{Current policy context}

Maximising use of scientific information in policy is hindered by three issues: (i) presentation of the scientific information, (ii) lack of integration with economic information, and (iii) existing rules and regulations within policy. SEEA has potential as an information system but is underutilised. Emissions reduction policy is not incorporating all options partly because of the information reported under the UNFCCC guidelines. Key characteristics of accounting systems are outlined in Table 1, which show that carbon stock and flow accounts align structurally with the SNA, and are complementary but additional to the current National Greenhouse Gas Inventory (NGGI) used in Australia (DoEE, 2015). Our case study of carbon accounting is from Australia, but the accounting systems being compared accord with the rules and guidelines from international organisations (European Commission et al., 2008; IPCC, 2014); hence the comparisons have global implications.

\subsection{Emissions reduction policy}

The UNFCCC objective is to limit atmospheric concentrations (stocks) of GHGs to prevent dangerous anthropogenic interference with the climate system (Article 2, UN, 1992). Article 3 states that policies and measures to deal with climate change should be comprehensive, cover all relevant sources, sinks and reservoirs of GHGs and adaptation, and comprise all economic sectors. Benefits of mitigation activities in terms of influencing the atmospheric carbon stock depend on the carbon stock in the biosphere and the longevity of its storage.

NGGI are the basis for assessing compliance with emissions reduction targets, under the UNFCCC and Kyoto Protocol. NGGI use standard methodologies for estimating and reporting GHG emissions and removals (IPCC, 2014) and report on net flows of carbon by land use categories and human activities (DoEE, 2015). However, reporting net flows does not address fully the UNFCCC objective, which is defined in terms of stocks, that is, $450 \mathrm{ppm}$ in the atmosphere.

Carbon storage and carbon sequestration are ecosystem services from forests that mitigate climate change. The carbon storage service is the avoided loss of carbon, and the carbon sequestration service is the removal of carbon from the atmosphere. Carbon dynamics in the biosphere differ in fundamental ways from fossil fuel emissions in terms of their reversibility, stability, longevity, carbon density and variability (Ajani et al., 2013; Prentice et al., 2007; Rittenhouse and Rissman, 2012). Ecological information about bi-directional gross flows, timescales, spatial relationships with land cover and land use, processes driving change, impacts of disturbance, and characteristics of their original stocks is essential for understanding carbon dynamics. For example, emissions from stable stocks may be sequestered into temporary stocks that are balanced in the short-term, but cause an increase in atmospheric $\mathrm{CO}_{2}$ concentrations in the longer-term.

Under the current reporting to the UNFCCC for the Kyoto Protocol (Article 3.4, UN, 2011), removals from forest management activities that are included in the NGGI cannot exceed 3.5\% of the base year GHG emissions. This cap limits the carbon credits that can be gained from forest management activities, so that incentives for reducing fossil fuel emissions are not diminished. In the revised rules for carbon accounting under the Paris Agreement, the aspiration is that all forms of emissions reduction can be incentivised without offsetting one form against another, but negotiations are on-going beyond CoP 24 in late 2018 (UN, 2018).

In Australia, no market value exists for carbon storage and sequestration in native forests because loss of carbon by harvesting is not considered a change in land use, and hence forest protection is not an approved abatement activity (Clean Energy Regulator, 2016). The value of carbon sequestration could be realised if market access was permitted under the Emissions Reduction Fund, which aims to achieve abatement at lowest cost (DoEE, 2017). Changing this national legislation is key to adopting the full suite of potential mitigation activities in Australia.

\subsection{Environmental accounts}

SEEA is used increasingly - by over 50 countries (UNSD, 2016) - to inform decisions about natural resources, including land management decisions, environment reporting, and attaining the SDGs (UNDP, 2015; Vardon et al., 2017). The SEEA reveals contributions of ecosystems to the economy and human well-being, and incorporates previously unrecognised goods and services provided by the environment (UN et al., 2014a,b).

The SEEA Central Framework (SEEA CF) (UN et al., 2014a) accounts for changes of stocks in physical and monetary terms, but does not specifically include carbon. However, flow accounts for expenditure on environmental protection and physical air emissions are included. 
Emissions by industries and households are reported by type of substance, including $\mathrm{CO}_{2}$ and other GHGs, and the money spent minimising emissions. Carbon accounts are included in the SEEA Experimental Ecosystem Accounts (SEEA EEA) (UN et al., 2014b) under three contexts: (i) stock of carbon; (ii) indicator of ecosystem condition, such as net carbon balance and primary productivity; and (iii) flows of ecosystem services, such as carbon sequestration and carbon storage. The carbon stock account in the SEEA EEA includes opening and closing stocks in three categories - biocarbon, geocarbon and fixed assets. Changes are classified as additions and reductions resulting from human or natural activities.

The main issues in implementing carbon accounting to report on emissions reductions include: (i) defining baseline forest carbon stocks (or carbon carrying capacity) from which to determine net change in carbon stock, ideally primary or old growth forest; (ii) assessing change in carbon stocks against this baseline, rather than the annual flow as carbon sequestration; (iii) quantifying risks of loss by disturbance; and (iv) distinguishing natural and human impacts. The challenge is how to use the longitudinal retrospective data in accounting to inform policy and scenarios analysis for emissions reduction. The information needed is current carbon stock, potential for change, processes that determine change, and impacts of disturbance.

A key benefit of having carbon accounting implemented as part of the SEEA, is that both economic and environmental issues relating to climate change mitigation and adaptation can be seen within a comprehensive framework. Thus changes in land use can be examined not just for changes in the stocks and flows of carbon but for other environmental factors such water yield, erosion control and biodiversity conservation, as well as economic issues such changes to industry mix, income and profits, and cost of environmental protection. The combination of both environmental and economic factors means that it is possible to assess the activities that provide the greatest environmental benefit at the least cost. Cost includes direct payments for environmental protection and management as well as net changes in income and profits across all industries. These broader issues are examined for a forest region in Australia in Keith et al. (2017).

\section{Methods}

\subsection{Study region}

The study region was the Central Highlands in Victoria, Australia where management of forests for climate change mitigation and wood production conflict. The region (735,655 ha) is approximately $100 \mathrm{~km}$ north-east of Melbourne (Fig. 1a), consisting predominantly of native forest on public land, with about half currently managed for wood production and half for conservation, as well as areas of softwood and hardwood plantations on private land. These plantations are monocultures of either exotic pines or non-local eucalypts. Public land in Australia used for commercial native timber production is managed under Regional Forest Agreements, through government legislation (DAWR, 2016). The Agreement for the Central Highlands is currently being re-negotiated, hence the imperative to improve information systems for decision-making.

The wet temperate, evergreen forests include montane ash (Eucalyptus regnans, E. delegatensis and E. nitens) that are among the most carbon-dense in the world (Keith et al., 2009), as well as mixed species eucalypt forests. These forests are subject to disturbance by wildfires and logging. Forest age was determined from stand-replacing disturbance events, including high-severity wildfire that kills montane ash forest and rainforest, and clearfell logging and slash burning of montane ash and mixed species forests. About half the area burnt in a major wildfire in 2009 resulted in stand replacement (Keith et al., 2014a).

\subsection{Carbon storage and sequestration}

Carbon accounting under SEEA EEA is spatially based, specifying land units tagged with land use history, baseline carbon stock, and calculated net annual emissions. Carbon stocks in biomass were modelled spatially across the landscape using site data of measured biomass, and spatial biophysical data, land cover and forest age. Annual changes in carbon stocks were calculated as additions due to tree growth; and reductions due to emissions from fire, collapse of dead standing trees, decomposition of dead biomass, and losses due to logging (Appendix A1). Changes in carbon stocks (1991-2015) were calculated based on disturbance history of fire and logging events. Projected changes in carbon stocks (2016-2065) were based on data for current carbon stock, and historical data to derive functions of carbon dynamics including carbon accumulation with age for each forest type, average stock reductions due to fire across the landscape, and due to logging under specific scenarios.

Valuation of ecosystem services of carbon storage and sequestration used the price for carbon abatement projects of $\$ 12.25$ per $\mathrm{tCO}_{2 \_ \text {e }}$ paid by the Australian Government Emissions Reduction Fund (Clean Energy Regulator, 2016). Carbon abatement in native forests in Australia currently does not have a market because of government regulation, but this was used as a market price equivalent (Appendix A1 1.6). The estimated value of the ecosystem service is equivalent to the revenue from production of goods and services. To calculate the Industry Value Added (IVA), which is the contribution to Gross Domestic Product, the estimated expenses for managing the forest were deducted (Appendix A1 1.6).

\subsection{Timber production}

Various data sources were compiled to determine area harvested (ha), wood yield $\left(\mathrm{m}^{3} \mathrm{ha}^{-1}\right)$, and wood volume $\left(\mathrm{m}^{3} \mathrm{yr}^{-1}\right)$ for each forest type (native forest mixed species and montane ash, and plantation hardwood and softwood) and product type (sawlogs and residual logs) over time (Appendix A2).

Valuation of the ecosystem service of native forest timber production used the reported stumpage value, representing the revenue from forest products less harvesting and haulage costs, and reported revenue and expenses to calculate IVA. Valuation of hardwood and softwood plantation production used a standard ratio of gross value of sales to IVA in forestry to estimate the value of ecosystem services used in production (Appendix A2).

\subsection{Calculating trade-offs}

Changes in carbon stocks (1991-2015) were calculated due to additions from growth and reductions from combustion and decomposition of waste material, wood product removal, and changes in age structure of the forest. Stocks were calculated for the total study area and disaggregated into areas logged, available for logging and unavailable for logging.

Trade-offs in terms of the impacts of management on carbon stocks were considered in the context of three conditions.

(i) Current: represented as the difference in carbon stock density in the same forest type, in this case montane ash forest, between areas logged and unlogged. The average stock was calculated across the age distribution in each area.

(ii) Historical: analysed as the counterfactual case with the difference in values of services if harvesting had not occurred. Carbon sequestration potential was represented by the difference in net change in carbon stock density between the areas logged and unlogged across all forest types.

(iii) Future: analysed as projections of annual changes in carbon stock from 2015 for 50 years. 

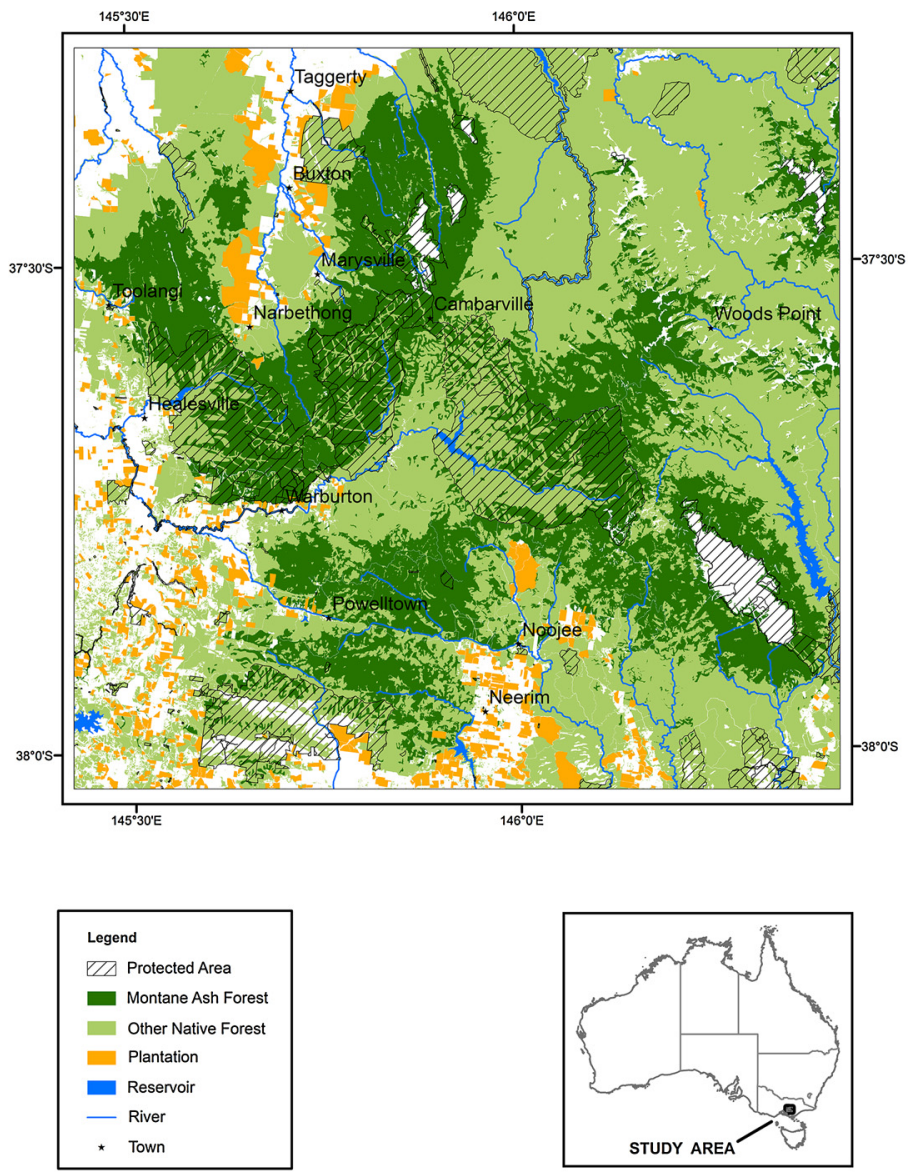

(a) Location and forest types.

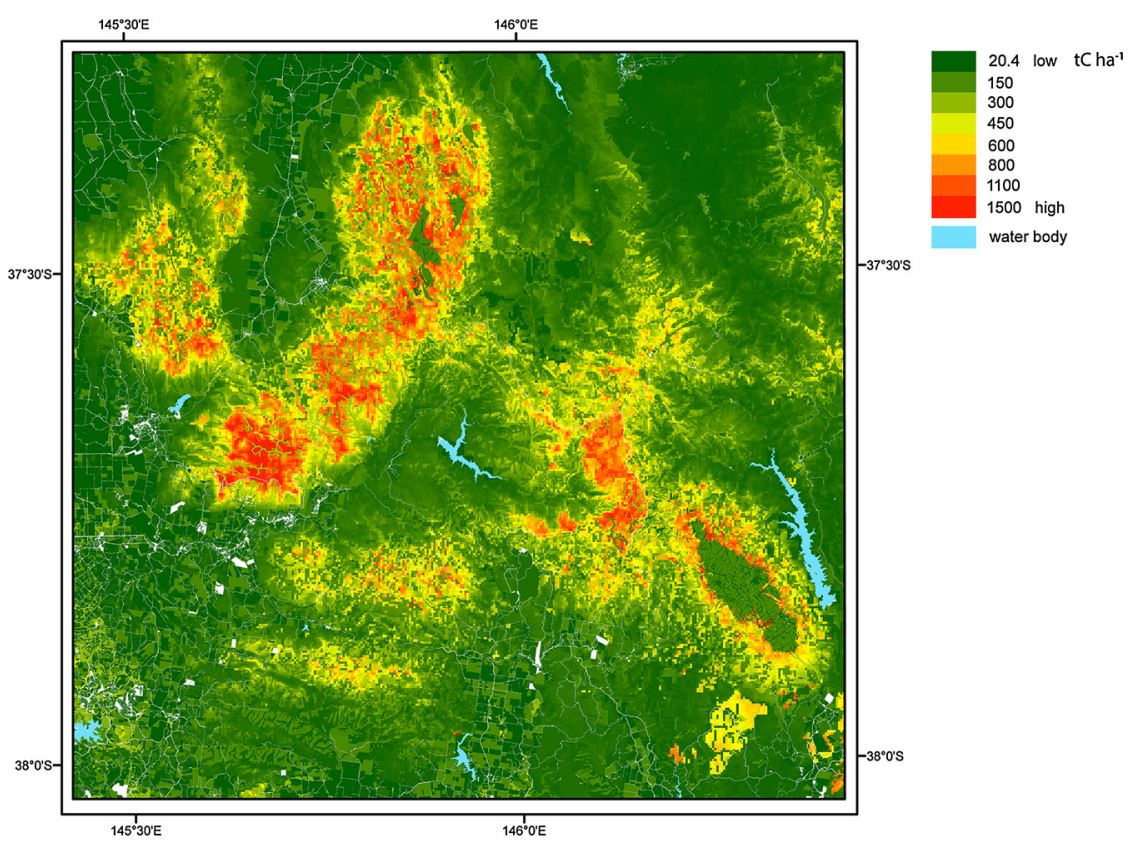

(b) Carbon stock density across all land cover types (2015)

Fig. 1. Central Highlands study area. 
Spatial distributions of the ecosystem services of carbon storage and timber provisioning were derived from their physical metrics in relation to land cover, land use, forest type, forest age and environmental conditions across the landscape. These metrics were continuous variables, range-normalised to derive indices between 0 and 1 , and then combined to derive an interaction index showing areas of common highest values of both ecosystem services. The index was displayed as five classes on the map for ease of comparison.

\section{Results}

\subsection{Carbon storage and sequestration}

Total carbon storage in the study area was $146 \mathrm{MtC}$ in 2015, calculated from the sum of area (ha) of each land cover class multiplied by the carbon stock density ( $\mathrm{tC} \mathrm{ha}{ }^{-1}$ ) (Table B.1). Distribution of carbon stock density across the landscape shows highest stocks in montane ash forest (Fig. 1b).

Net annual change in carbon stock was calculated from 1991 to 2015 (Table B.2), with an average value of $1.64 \mathrm{MtC} \mathrm{yr}^{-1}$ over 2011 2015. This represents the balance between additions due to growth and reductions due to combustion, decomposition and removal of stocks by timber harvesting. Positive net change represents the ecosystem service of carbon sequestration because $\mathrm{CO}_{2}$ is removed from the atmosphere and carbon is stored in the ecosystem. Negative net change, or emission, represents contribution of the land use to GHG emissions.

Reductions in carbon stocks were due to logging and fire. Gross reduction in carbon stock (1991 to 2015) due to logging was -14.2 MtC, compared with -3.4 MtC from all fires, and -2.4 MtC from the 2009 fire. Reductions from fires were re-gained within 5 years through sequestration by the regenerating vegetation.

Net change in carbon stock is the metric used in carbon accounting for the Emissions Reduction Fund (Clean Energy Regulator, 2016). Total value of the ecosystem service of carbon sequestration was $\$ 73.7$ million $\mathrm{yr}^{-1}$ (averaged over 2011-2015), shown for each land cover type and time series from 1991 to 2015 (Table B.3). Different values, depending on national and international carbon prices, are shown in Table B.4. The IVA for carbon sequestration of $\$ 48.8$ million $\mathrm{yr}^{-1}$ was derived from the income from carbon sequestration (Table B.3) and expenses in managing the forest (Table B.5).

\subsection{Timber production}

Native forest area, yield and volume harvested are shown from 1991 to 2014 (Figs. B.1, B.2, B.3). Financial information summarising the operations of VicForests is shown for Victoria (Table B.6), and the Central Highlands study area (Table B.7). The wood volume supplied from the study area of $724,300 \mathrm{~m}^{3} \mathrm{yr}^{-1}$ had a value of the ecosystem service of \$18.7 million and an IVA of \$12.2 million (in 2013-14).

Hardwood and softwood plantation areas and volumes of sawlogs and pulplogs harvested and their values are shown from 2004 to 2015 (Table B.8). The gross value of sales from timber production, the resource rent and IVA are shown for Australian plantation production (Table B.9) and the proportion in the Central Highlands study area (Table B.10). The wood volume supplied of $539,700 \mathrm{~m}^{3}$ had a value of the ecosystem service of $\$ 9.1$ million and an IVA of $\$ 29.9$ million (in 2013-14).

Spatial distribution of timber harvesting was recorded since 1932 (Fig. 2). The nominal harvesting age is 80 years, although current median age of harvesting is 68 years (Keith et al., 2015).

\subsection{Time series of supply of ecosystem services}

Values of the ecosystem service and IVA of carbon sequestration were greater than that for timber provisioning from native or plantation forests (Fig. 3). The exception was the year after the 2009 wildfire due to emissions from combustion, but values increased the following year with regeneration. IVA for plantation forestry had an increasing trend, surpassing that of native forestry for the last four years. Wood volume produced by plantations is $75 \%$ of that from native forests, even though the area of land under plantations is $14 \%$ of that under native forest available for harvest, suggesting substantially greater intensity of land use in plantations.

\subsection{Trade-offs between the use of ecosystem services}

Managing native forests for timber production decreases carbon storage due to combustion and decomposition of waste material, wood product removal, and reducing forest age. Carbon stocks and stock changes are defined by areas logged and burnt (Table B.11). Trade-offs between ecosystem services were defined by three conditions (Table 2):

(i) Current: Unlogged forest had higher carbon stocks by 142.8 tC $\mathrm{ha}^{-1}$, valued at $\$ 6413 \mathrm{ha}^{-1}$. The difference in carbon stock for the montane ash forest that had been logged was $8.76 \mathrm{MtC}$, worth $\$ 393$ million.

(ii) Historical: Carbon sequestration potential was $2.98 \mathrm{tC} \mathrm{ha}^{-1} \mathrm{yr}^{-1}$ (averaged 1991-2015) (Table B.11). Total difference in carbon sequestration was $0.344 \mathrm{MtC}_{\mathrm{yr}^{-1}}$ (2.98 $\mathrm{tC} \mathrm{ha}^{-1} \mathrm{yr}^{-1} \mathrm{x}$ 115,421 ha area logged), worth $\$ 15.5$ million $\mathrm{yr}^{-1}$ in ecosystem services and $\$ 12.6$ million $\mathrm{yr}^{-1}$ in IVA.

(iii) Future: Difference in projected carbon stock over 50 years with logging (80.30 MtC) and without logging ( $96.78 \mathrm{MtC})$ was 16.48 MtC (Fig. B.4), or $0.330 \mathrm{MtC} \mathrm{yr}^{-1}$ (1.13 tC $\mathrm{ha}^{-1} \mathrm{yr}^{-1}$ x 291,607 ha area available for logging), worth $\$ 740$ million over 50 years or $\$ 14.8$ million $\mathrm{yr}^{-1}$ in ecosystem services and $\$ 12.0$ million $\mathrm{yr}^{-1}$ in IVA.

Slightly lower carbon sequestration projected into the future than that calculated for the past reflects the age structure of the forest, particularly increasing age of 1939 regeneration and hence lower rates of carbon accumulation.

If native forest harvesting had not occurred in the past, or ceased to occur in the future, then $\$ 12.2$ million $\mathrm{yr}^{-1}$ would be foregone in IVA from timber production. Historically, continued forest growth within this area would have resulted in gains in carbon sequestration of $\$ 12.6$ million $\mathrm{yr}^{-1}$ in IVA. In the future, if logging ceased now and new areas were not logged, the gain in carbon stocks would have an IVA value of $\$ 12.0$ million $\mathrm{yr}^{-1}$.

Areas of greatest conflict in the trade-off were identified from the spatial distributions of the ecosystem services of carbon storage and timber provisioning. This interaction index showed the areas with potential for conflict where land tenure is available for logging, forests are older, species are valuable for timber and have high carbon stocks (Fig. 4).

\section{Discussion}

\subsection{Opportunities for carbon accounting to inform policy}

Our study demonstrates the benefit of comprehensive carbon accounts including stocks and flows in both physical and monetary metrics, which can be developed over any spatial and temporal scale. Such accounting provides a common approach that can be used for a range of policy needs including climate change mitigation, sustainable development and forest management. This essentially reconciles the various accounts within the current SEEA CF and SEEA EEA, and thus has the potential to improve clarity and efficiency. SEEA accounting complements and extends information currently reported in the national inventories under the UNFCCC and means additional indicators can be derived to address specific issues.

Carbon accounts distinguish two ecosystem services: (i) carbon 


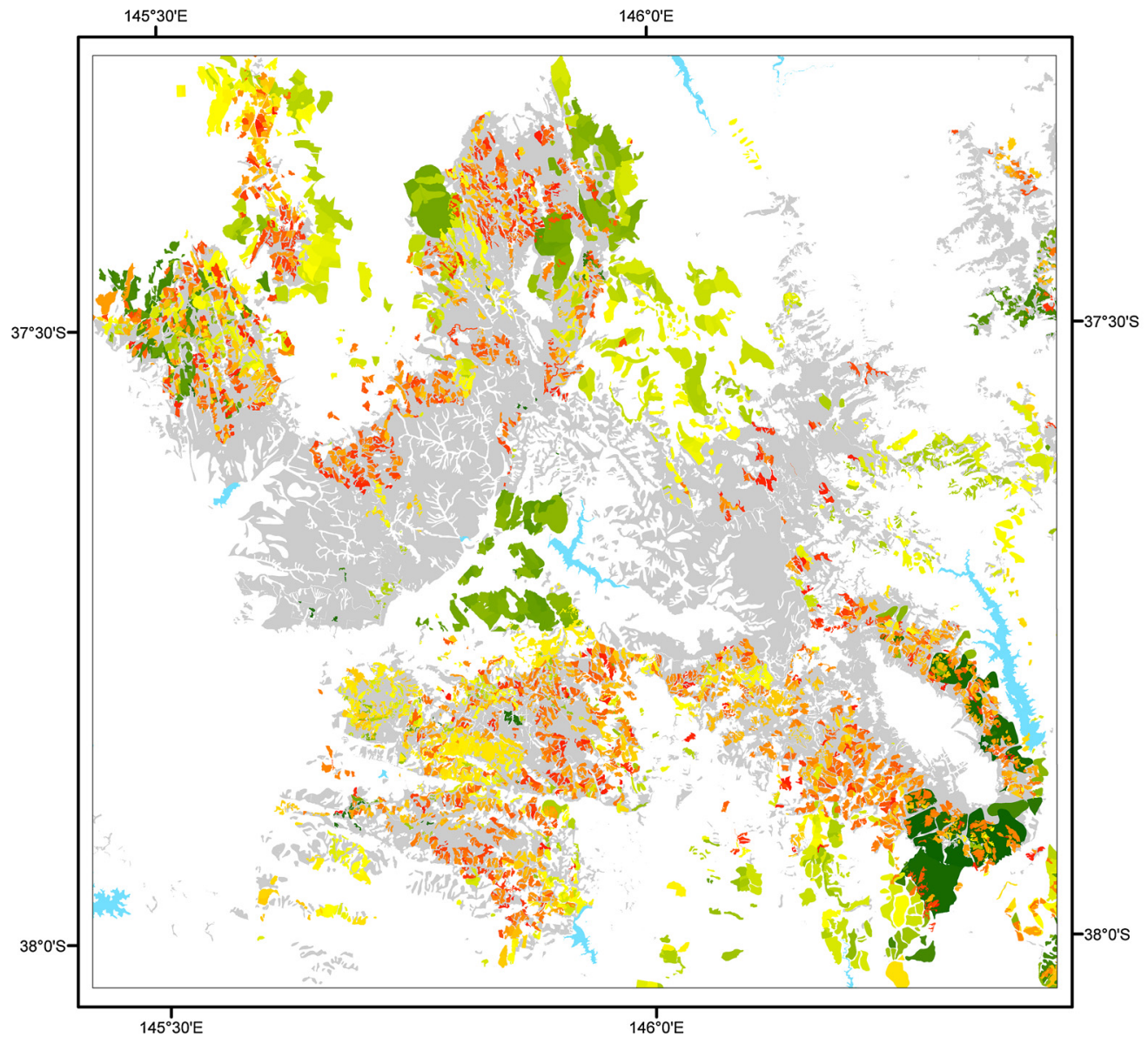

\section{Year of Last Logging}

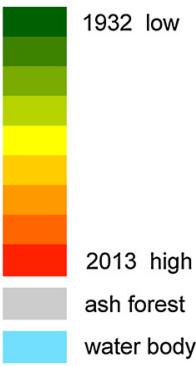

Fig. 2. Distribution of logging history in all forest types.

storage - determined by net stock change compared with a baseline of the asset of carbon stock, and (ii) carbon sequestration - a flow as the rate of carbon uptake by terrestrial ecosystems (net ecosystem carbon balance) and removal from the atmosphere each year. Both ecosystem services need to be accounted for in emissions reduction policy and abatement activities. The linked physical and economic data in the accounts allows these ecosystem services to be directly linked to the economy.

Comprehensive carbon stock and flow accounts directly address current issues for emissions reduction reporting (section 2.2). The accounting differentiates biocarbon and geocarbon, thus allowing specific policies and targets to be set for each, so that 'offsetting' of emissions
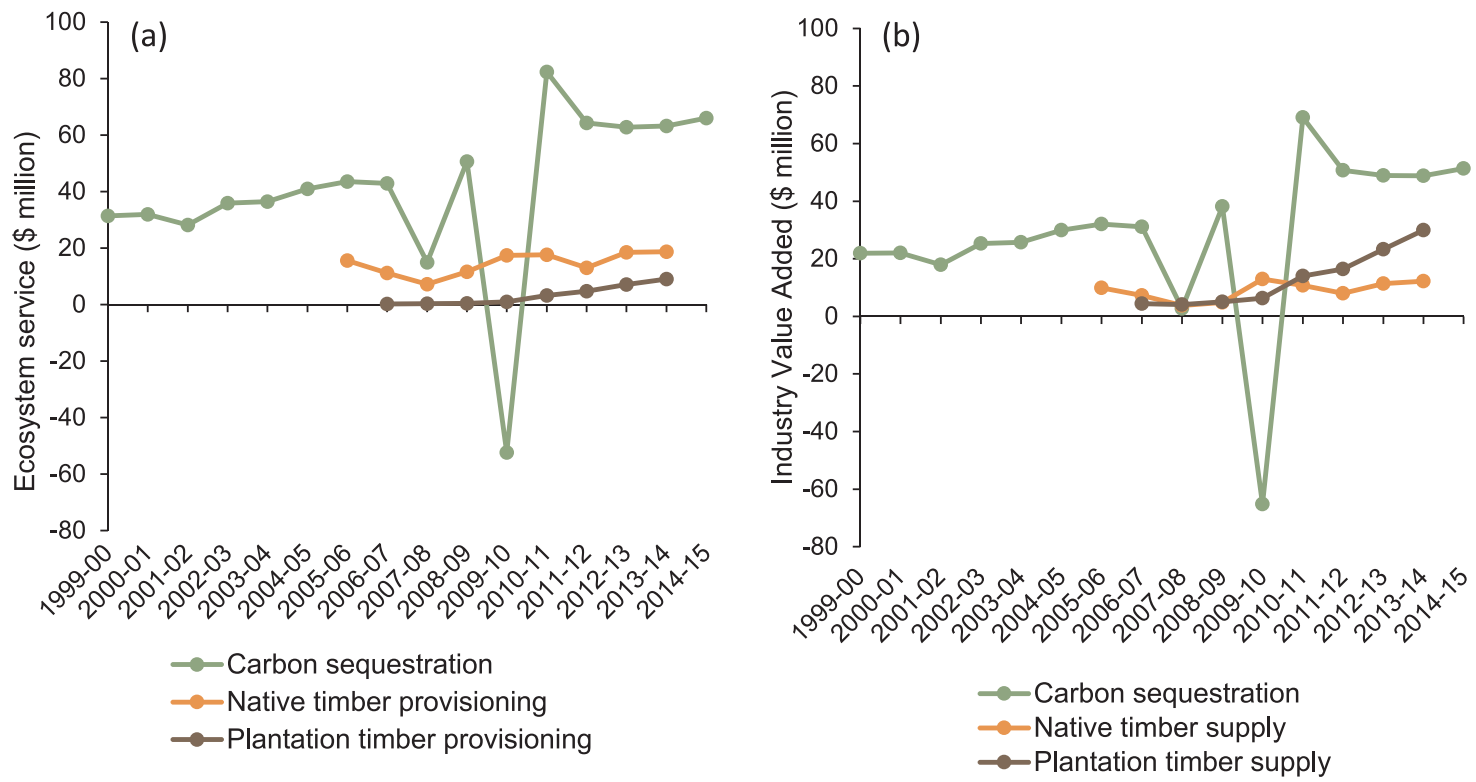

Fig. 3. Value of ecosystem services (a), and industry value added (b). 
Table 2

Change in carbon stock in each land management area under scenarios of with and without logging.

\begin{tabular}{|c|c|c|c|c|c|c|c|}
\hline \multirow[b]{2}{*}{ Area - montane ash forest (ha) } & \multirow{2}{*}{$\begin{array}{l}\text { Area 1. Previously } \\
\text { logged }\end{array}$} & \multicolumn{2}{|c|}{ Area 2. Available for logging } & \multicolumn{2}{|c|}{$\begin{array}{l}\text { Areas } 1 \& 2 \text {. } \\
\text { Total area available for logging }\end{array}$} & \multirow[t]{2}{*}{$\begin{array}{l}\text { Difference } \\
\text { unlogged - logged }\end{array}$} & \multirow[t]{2}{*}{$\begin{array}{l}\text { Area 3. Unavailable for } \\
\text { logging }\end{array}$} \\
\hline & & 143,718 & & 205,059 & & & \\
\hline Current condition (2015) & logged & unlogged & & & & & \\
\hline $\mathrm{C}$ stock density $\left(\mathrm{tC} \mathrm{ha} \mathrm{h}^{-1}\right)$ & 368.1 & 510.9 & & & & 142.8 & \\
\hline Area - all forest types (ha) & 115,421 & 176,186 & 176,186 & 291,607 & 291,607 & & 441,130 \\
\hline $\begin{array}{l}\text { Historical condition } \\
\quad(1991-2015)\end{array}$ & logged & unlogged & & $\begin{array}{l}\text { logged \& } \\
\text { unlogged }\end{array}$ & & & unlogged \\
\hline Opening C stock 1991 (MtC) & 32.37 & 24.94 & & 57.31 & & & 61.74 \\
\hline $\begin{array}{l}\text { Net change in C stock (MtC } 25 \\
\mathrm{yr}^{-1} \text { ) }\end{array}$ & -1.62 & 10.65 & & 9.02 & & & 57.31 \\
\hline 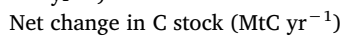 & -0.065 & 0.426 & & 0.361 & & & \\
\hline $\begin{array}{l}\text { Net change in } \mathrm{C} \text { stock density } \\
\left(\mathrm{tC} \mathrm{ha} \mathrm{har}^{-1} \mathrm{yr}^{-1}\right)\end{array}$ & -0.56 & 2.42 & & 1.24 & & $\begin{array}{l}2.98 \text { over } \\
115,421 \text { ha }\end{array}$ & 5.20 \\
\hline Closing C stock 2015 (MtC) & 30.75 & 35.58 & & 66.33 & & & 79.38 \\
\hline $\begin{array}{c}\text { Future projection } \\
(2016-2065)\end{array}$ & no logging & no logging & logging & no logging & logging & & no logging \\
\hline Opening C stock 2015 (MtC) & 30.75 & 35.58 & 35.58 & 66.35 & 66.35 & & 79.38 \\
\hline $\begin{array}{l}\text { Net change in C stock (MtC } \\
50 \mathrm{yrs}^{-1} \text { ) }\end{array}$ & 17.35 & 13.08 & -3.39 & 30.43 & 13.96 & & 21.20 \\
\hline Net change in $\mathrm{C}$ stock $\left(\mathrm{MtC}_{\mathrm{yr}}^{-1}\right)$ & 0.347 & 0.262 & -0.068 & 0.609 & 0.297 & & 0.424 \\
\hline $\begin{array}{l}\text { Net change in C stock density } \\
\left(\mathrm{tC} \mathrm{ha}^{-1} \mathrm{yr}^{-1}\right)\end{array}$ & 3.01 & 1.49 & -0.39 & 2.087 & 0.957 & $\begin{array}{l}1.13 \text { over } \\
291,607 \text { ha }\end{array}$ & 2.41 \\
\hline Closing C stock 2065 (MtC) & 48.12 & 48.66 & 32.18 & 96.78 & 80.30 & & 102.51 \\
\hline
\end{tabular}

from one by the removals in another would not be permitted if the qualities of the carbon stocks differed (Ajani and Comisari, 2014). Baseline carbon stocks are defined spatially and temporally in the accounts with land units tagged with land cover and land use, such that carbon carrying capacity can be defined for an old growth or primary forest. Carbon stock changes are calculated from annual additions and reductions. Land use history is used to determine losses from disturbance and to distinguish between impacts of natural and human activities. Separate supply and use accounts identify the economic activities causing these changes to carbon stocks and link to the national accounts. Abatement activities are assessed for their carbon sequestration potential as the difference between the current carbon stock and the carbon carrying capacity. Transparent attribution of carbon stock changes provides information to determine compliance of activities
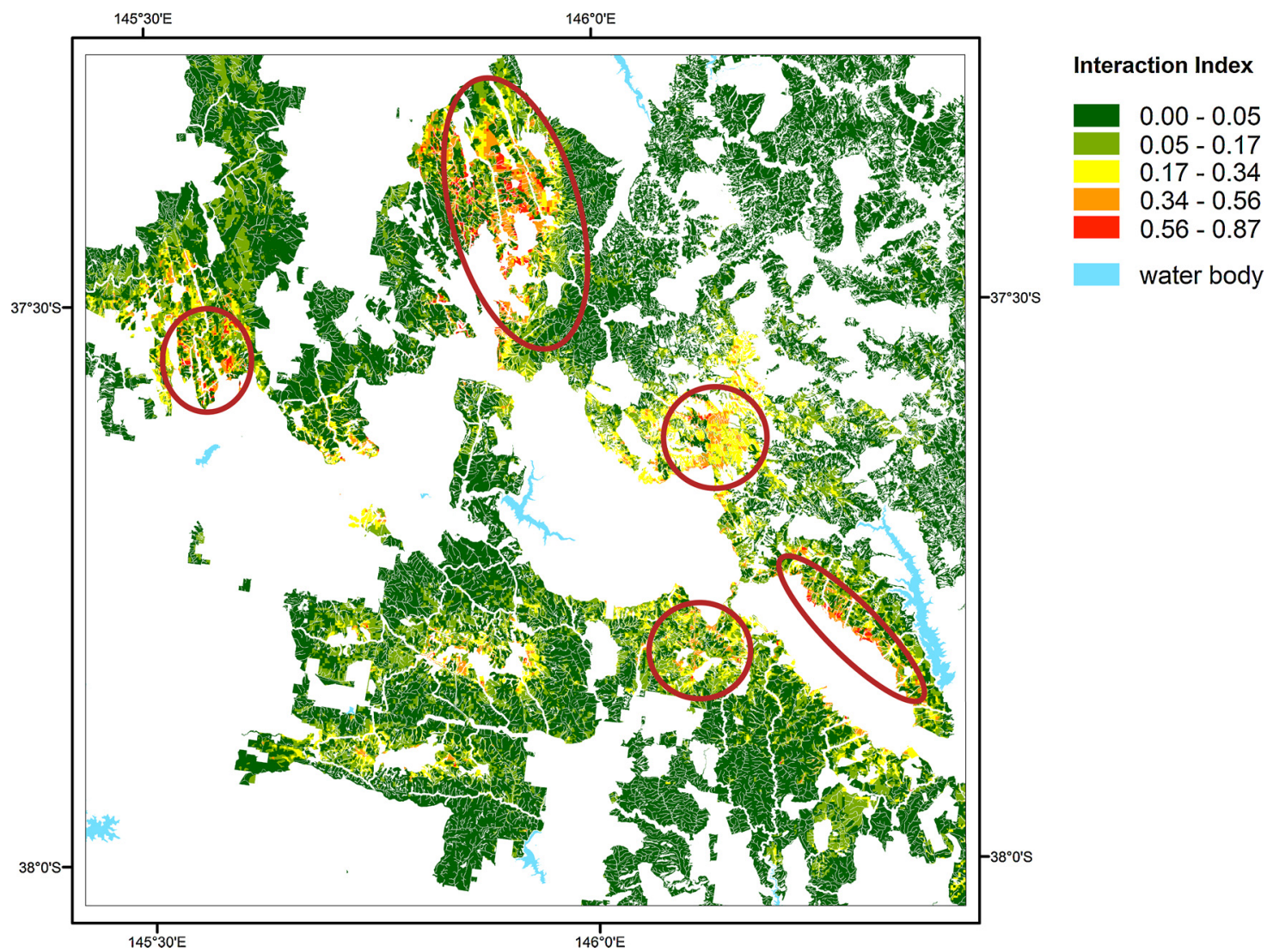

Fig. 4. Spatial distribution of the interaction of ecosystem services of carbon storage and timber provisioning in the area with land tenure available for logging. Areas of highest values in red identify the 'hotspots'. 
with emissions reduction targets according to the criteria of humaninduced activities, additionality, leakage, and permanence.

Research priorities for carbon accounting include: (i) assessing carbon stocks in the biosphere according to the quality of the stock in relation to longevity, stability, resilience and density; and (ii) quantifying the spatial variation of carbon stocks in vegetation and soil across the landscape and the associated balance between coverage and accuracy (UNEP, 2017).

\subsection{Accounts reveal the mitigation potential of native forests}

The study showed clearly the mitigation benefit of carbon storage and sequestration in native forests compared to timber harvesting. This trade-off was analysed in terms of values of ecosystem services, both as actual changes that occurred in the past and as future changes projected under different management scenarios.

Both native timber production and carbon sequestration contribute a similar value to the economy (about $\$ 12$ million $\mathrm{yr}^{-1}$ ). The difference is that managing forests for carbon storage and sequestration provides additional benefits. Increased water yield would have a value of $\$ 2.5$ million $\mathrm{yr}^{-1}$ in ecosystem services and $\$ 8.1$ million $\mathrm{yr}^{-1}$ in IVA (Keith et al., 2017). Other benefits, as yet unquantified, include ecosystem services for culture and recreation and habitat for biodiversity. Hence, managing native forests for conservation maximises carbon stocks and enhances other ecosystem services.

Analysing trade-offs using accounting allows land use options to be explored. In the study region, benefits were identified from transitioning away from native forest timber production and increasing wood supply from plantations. The existing plantation estate has a greater potential for wood supply than current demand, and potential exists for plantation expansion on previously cleared land. Hence, substitution of native forest timber by future plantation products does not involve conversion of native forest land.

The increasing IVA of plantation timber over the last decade (Fig. 3b) indicates the feasibility of substituting timber from native forests with timber from plantations, including both sawlogs and pulplogs. Additionally, pulplogs from the study region could be substituted by recycled paper. Hence, a reduction in timber production from native forests should not mean cessation of downstream economic activities. Although numerous previous reports have investigated potential changes in the native forest timber industry in the Central Highlands (Appendix C1), this study contributes an integrated analysis of environmental and economic factors that enables decisions to maximize public benefits. The accounts also reveal differences in economic contributions of industries and their values generated for different beneficiaries (Appendix C2).

Analysing trade-offs in other regions will be influenced by many factors, such as risks of carbon stock loss from ecosystems, product mix and prices of carbon. Risk of loss to the ecosystem service of carbon storage differs due to the types of disturbances and characteristics of ecosystems. Usually, stock losses are greater in forests managed for timber harvesting (30-70\% loss across the landscape) compared with wildfires (about 10\% loss) (Keith et al., 2014a, b). Product mix, such as pulp and paper, sawn timber and substitution with bioenergy, influence the carbon stocks in the system and their longevity (Keith et al., 2015), and these variations can be incorporated in the SEEA accounting system.

Carbon prices have been volatile over time and between jurisdictions, thus influencing relative values of ecosystem services (Khatun, 2011). The carbon price used in this study should be considered a minimum because it is a government purchase price from reverse auction and is constrained by institutional regulations. Additionally, activities that reduce emissions typically deliver valuable co-benefits contributing to the viability of projects, for example, economic benefits from energy efficiency, utilising waste products, improving productivity from revegetation, increasing soil carbon, and reducing environmental problems like erosion, water pollution and salinity (Ellison et al., 2011). Most importantly, the carbon price does not reflect the social cost of emissions on future generations. Average values of the social cost are estimated at $\$ 58 \mathrm{tC}^{-1}\left(\$ 212 \mathrm{tCO}_{2}{ }^{-1}\right)$ based on a literature survey (Tol, 2005), or $\$ 85 \mathrm{tC}^{-1}\left(\$ 314 \mathrm{tCO}_{2}{ }^{-1}\right)$ used in the Stern Review (Stern, 2006). Using these carbon prices to calculate IVA for carbon sequestration in the area logged changes the trade-off from $\$ 12.6$ million $\mathrm{yr}^{-1}$ (Australian Emissions Reduction Fund) to \$265 million $\mathrm{yr}^{-1}$ (Tol, 2005) or $\$ 393$ million $\mathrm{yr}^{-1}$ (Stern, 2006). Identifying beneficiaries in the SEEA provides useful context for interpretation.

\subsection{Recommendations for policy and markets}

SEEA-based carbon accounts provide information that broadens policy options for mitigation activities. Under the UNFCCC flows-based inventory, activities focus on reducing emissions and increasing removals. Comprehensive carbon stock and flow accounts in both physical and monetary metrics identify the mitigation benefits of protecting and increasing primary carbon stocks. Changes to definitions and rules for carbon accounting under the Paris Agreement would allow this mitigation benefit of protecting native forests to be realised.

Storage of carbon in forests is an ecosystem service that benefits the global community. The potential for reducing emissions by avoiding deforestation and degradation and promoting regeneration and restoration is estimated to represent $24-33 \%$ of all mitigation (International Sustainability Unit, 2015). However, under current international rules for reporting emissions, a large proportion of the emissions due to degradation are not included and potential for sequestration has no market. The environmental-economic accounting used in this study helped identify policy and market instruments required to value the ecosystem service of carbon storage in native forests. By applying a potential market price for carbon, we identified the benefit of native forest protection as a carbon abatement activity, and compared this value to that of current forest management for timber harvesting that reduces carbon stocks. The current lack of a market due to Australian Government regulations severely restricts mitigation options and associated co-benefits.

The GHG inventories required for reporting under the Kyoto Protocol will likely be inadequate for reporting on the carbon budget required for the Paris Agreement. This has been seen already with the additional reporting required for carbon stocks in REDD (Reducing Emissions from Deforestation and Degradation) projects (UN-REDD, 2017). As the guidance and rules for both the Paris Agreement and the SEEA EEA are being negotiated, it is imperative that principles of comprehensiveness, consistency and compatibility are observed. Efficiencies can be gained by developing a common SEEA-based framework that is applied to a range of policy demands, including the Paris Agreement on Climate Change and the Sustainable Development Goals. Synergies between these international agreements are emerging. For example, submissions to the Paris Rulebook for NDCs include principles and obligations for food security, human rights, sustainable development and ecosystem integrity (UN, 2017).

Application of SEEA to climate change mitigation policy is emerging and now is the time to ensure a common approach. We demonstrated that SEEA provides relevant information for policy needs in the Central Highlands, using the new development of analysis of data in the accounts in terms of historical changes, current differences and trade-offs, and future scenarios. Other examples using SEEA-based accounts are from Guatemala for forests (Castaneda et al., 2017) and for carbon from The Netherlands (Lof et al., 2017), which is proposed for use in the Effort Sharing Regulation of the European Commission (European Commission, 2016) for assessing emissions reduction targets for the Paris Agreement. The feasibility of linking these systems was demonstrated in an experimental exercise mapping the UNFCCC GHG inventory to the SEEA air emissions tables, although concordance of classification of human activities with technological processes, and 
boundaries of residents with economic activities and national territories, remain issues (Vetrella et al., 2017). The advantage of the SEEA for policy applications is the ability to relate physical flows to production and consumption (Tubiello et al., 2017).

Our recommendation is to use the SEEA as a single comprehensive carbon stock and flow account to provide the information system in which data can be stored, extracted and analysed to inform a range of policy applications. Such a system is likely to improve efficiency, comprehensiveness and independence of the information.

\section{Funding}

This work was supported by Fujitsu Laboratories Ltd Japan and the National Environment Science Programme of the Australian Department of the Environment and Energy.

\section{Appendix A. Supplementary data}

Supplementary material related to this article can be found, in the online version, at doi: https://doi.org/10.1016/j.envsci.2018.11.001.

\section{References}

Ajani, J., Keith, H., Blakers, M., Mackey, B.G., King, H.P., 2013. Comprehensive carbon stock and flow accounting: a national framework to support climate change mitigation policy. Ecol. Econ. 89, 61-72.

Ajani, J., Comisari, P., 2014. Towards a Comprehensive and Fully Integrated Stock and Flow Framework for Carbon Accounting in Australia. Australian National University, Australia. https://coombs-forum.crawford.anu.edu.au/publication/hc-coombspolicy-forum/4708/carbon-accounting-australia.

Castaneda, J.P., Castillo, F.C., Matias, I., et al., 2017. Implementing natural capital accounting in developing countries: public-academic partnerships and policy uptake in Guatemala. Chapter 12. In: Vardon, M. (Ed.), Forum on Natural Capital Accounting for Better Policy Decisions: Taking Stock and Moving Forward. World Bank WAVES, Washington DC, USA. https://www.wavespartnership.org/en/knowledge-center/ forum-natural-capital-accounting-better-policy-decisions-taking-stock-and-moving .

Clean Energy Regulator, 2016. Emissions Reduction Fund, Opportunities for the Land Sector - Sequestration Decision Tree. http://www.cleanenergyregulator.gov.au/ DocumentAssets/Documents/Sequestration\%20decision\%20tree\%202016.pdf.

DAWR, 2016. Department of Agriculture and Water Resources. Regional Forest Agreements. http://www.agriculture.gov.au/forestry/policies/rfa.

DoEE, 2015. Department of the Environment and Energy. National Inventory Report. . http://www.environment.gov.au/system/files/resources/97197b1e-07b9-4e6fa08e-0f6145e681e5/files/national-inventory-report-2015-vol2.pdf.

DoEE, 2017. Department of the Environment and Energy. Emissions Reduction Fund. http://www.environment.gov.au/climate-change/government/emissions-reduction fund.

Ellison, D., Lundblad, M., Petersson, H., 2011. Carbon accounting and the climate politics of forestry. Environ. Sci. Policy 14, 1062-1078.

Erb, K.H., Kastner, T., Ch, Plutzar, et al., 2017. Unexpectedly large impact of forest management and grazing on global vegetation biomass. Nature 553, 73-76.

European Commission, International Monetary Fund, Organisation for Economic Co-operation and Development, United Nations, World Bank, 2008. System of National Accounts. http://unstats.un.org/unsd/nationalaccount/sna2008.asp.

European Commission, 2016. European Commission Proposal for an Effort Sharing Regulation 2021-2030. https://ec.europa.eu/clima/policies/effort/proposal_en.

Friedlingstein, P., et al., 2014. Uncertainties in CMIP5 climate projections due to carbon cycle feedbacks. J. Clim. 27, 512-526.

Gasser, T., Guivarch, C., Tachiiri, K., Jones, C.D., Ciais, P., 2015. Negative emissions physically needed to keep global warming below $2^{\circ} \mathrm{C}$. Nat. Commun. 6, 7958. https:// doi.org/10.1038/ncomms8958.

Grassi, G., House, J., Dentener, F., Federic, S., den Elzen, M., Penman, J., 2017. The key role of forests in meeting climate targets requires science for credible mitigation. Nat. Clim. Change 7, 220-228.

Griscom, B., Shoch, D., Stanley, B., Cortez, R., Virgilio, N., 2009. Sensitivity of amounts and distribution of tropical forest carbon credits depending on baseline rules. Environ. Sci. Policy 12, 897-911.

Griscom, B., Adams, J., Ellis, P., 2017. Natural climate solutions. Proc. Natl. Acad. Sci. 114 (44), 11645-11650.

Hieke, S., Ch, Thies, Stoppel, J., 2018. Wenn Wälder wieder wachsen, eine Waldvision für Klima, Mensch und Natur. Basiert auf der Studie: Waldvision Deutschland, Beschreibung von Methoden, Annahmen und Ergebnissen, Öko-Institut e. V. 2018, im Auftrag von Greenpeace. https://www.greenpeace.de/sites/www.greenpeace.de/ files/publications/s02061_greenpeace_studie_waldvision.pdf.

Houghton, R.A., Byers, B., Nassikas, A.A., 2015. A role for tropical forests in stabilizing atmospheric $\mathrm{CO}_{2}$. Nat. Clim. Change 5, 1022-1023.

IPCC, 2014. In: Hiraishi, T. (Ed.), Revised Supplementary Methods and Good Practice Guidance Arising from the Kyoto Protocol. IPCC, Switzerland. http://www.ipccnggip.iges.or.jp/public/kpsg/index.html.
IPCC, 2018. Global Warming of $1.5^{\circ} \mathrm{C}$. Special Report SR15. . http://ipcc.ch/report/ sr15/.

International Sustainability Unit, 2015. Tropical Forests: A Review. The Prince's Charities' International Sustainability Unit, London. http://www.pcfisu.org/ resources/.

Keith, H., Mackey, B.G., Lindenmayer, D.B., 2009. Re-evaluation of forest biomass carbon stocks and lessons from the world's most carbon dense forests. Proc. Natl. Acad. Sci. U. S. A. 106 (28), 11635-11640.

Keith, H., et al., 2014a. Accounting for biomass carbon stock change due to wildfire in temperate forest landscapes in Australia. PLoS One 9 (9), e107126.

Keith, H., et al., 2014b. Managing temperate forests for carbon storage: impacts of logging versus forest protection on carbon stocks. Ecosphere 5 (6), 75.

Keith, H., Lindenmayer, D.B., Macintosh, A., Mackey, B.G., 2015. Under what circumstances do wood products from native forests benefit climate change mitigation? PLoS One 10 (10), e0139640.

Keith, H., Vardon, M., Stein, J.A., Stein, J.L., Lindenmayer, D., 2017. Ecosystem accounts define explicit and spatial trade-offs for managing natural resources. Nat. Ecol. Evol. $1,1683-1692$.

Khatun, K., 2011. Reconciling timber provision with carbon sequestration opportunities in the tropical forests of Central America. Environ. Sci. Policy 14, 1091-1102.

Le Quéré, et al., 2016. Global carbon budget 2016. Earth Syst. Sci. Data 8, 1786-1793.

Lindenmayer, D.B., 2018. Flawed forest policy: flawed regional forest agreements. Australas. J. Environ. Manag. 25 (3), 258-266. https://doi.org/10.1080/14486563. 2018.1466372

Lof, M., Schenau, S., de Jong, R., Remme, R., Graveland, C., Hein, L., 2017. The SEEA EEA carbon account for the Netherlands. $23^{\text {rd }}$ London Group Meeting on Environmental Accounting. https://seea.un.org/sites/seea.un.org/files/lg23_the_seea_eea_carbon account_lg2017.pdf.

McKibbin, W.J., Wilcoxen, P.J., Morris, A.C., Panton, A.J., 2017. Climate Change and Monetary Policy: Dealing With Disruption. The Climate and Energy Economics Policy Discussion Paper. Brookings Institute. https://www.brookings.edu/wpcontent/uploads/2017/12/es_20171201_climatechangeandmonetarypolicy.pdf.

MEA, 2005. Millennium Ecosystem Assessment. Synthesis: Ecosystems and Human Wellbeing. https://www.millenniumassessment.org/documents/document.356.aspx.pdf.

Medrilzam, D., et al., 2017. Linking natural capital accounts and development policy: the case of Indonesia's intended national determined contribution. Chapter 14. In: Vardon, M. (Ed.), Forum on Natural Capital Accounting for Better Policy Decisions: Taking Stock and Moving Forward. World Bank WAVES, Washington DC, USA. https://www.wavespartnership.org/en/knowledge-center/forum-natural-capitalaccounting-better-policy-decisions-taking-stock-and-moving.

Palacios-Agundez, I., Onaindia, M., Potschin, M., Tratalos, J.A., Madariaga, I., HainesYoung, R., 2015. Relevance for decision-making of spatially explicit, participatory scenarios for ecosystem services in an area of a high current demand. Environ. Sci. Policy 54, 199-209.

Prentice, I.C., et al., 2007. The carbon cycle and atmospheric carbon dioxide content. Chapter 3. Third Assessment Report of Working Group 1 of the Intergovernmental Panel on Climate Change. IPCC, Geneva, Switzerland. https://www.ipcc.ch/ ipccreports/tar/wg1/pdf/WGI_TAR_full_report.pdf.

Remme, R., Edens, B., Schröter, M., Hein, L., 2015. Monetary accounting of ecosystem services: A test case for Limburg province, The Netherlands. Ecol. Econ. 112, $116-128$.

Rittenhouse, C.D., Rissman, A.R., 2012. Forest cover, carbon sequestration, and wildlife habitat: policy review and modelling tradeoffs among land-use change scenarios. Environ. Sci. Policy 21, 94-105.

Ruckelshaus, M., et al., 2015. Notes from the field: lessons learned from using ecosystem service approaches to inform real-world decisions. Ecol. Econ. 115, 11-21.

Ruijs, A., van der Heide, M., van den Berg, J., 2017. Natural capital accounting for the sustainable development goals - current and potential uses and steps forward. $2^{\text {nd }}$ Forum on Natural Capital Accounting for Better Policy. WAVES Policy Forum, The Hague, November 2017. . https://www.wavespartnership.org/sites/waves/files/ images/Ruijs\%20et\%20al\%20-\%20NCA\%20for\%20SDGs\%20-\%20Forum $\% 20$ version.pdf.

Spanò, M., Leronni, V., Lafortezza, R., Gentlile, F., 2017. Are ecosystem service hotspots located in protected areas? Results from a study in Southern Italy. Environ. Sci. Policy 73, 52-60.

Steffen, W., Alexander, D., Rice, M., 2017. Critical Decade 2017: Accelerating Climate Action. https://www.climatecouncil.org.au/critical-decade-2017.

Stern, N., 2006. Stern Review: The Economics of Climate Change. Report to the Prime Minister and Chancellor, United Kingdom. . http://webarchive.nationalarchives.gov. uk/20100407172811/http://www.hm-treasury.gov.uk/stern_review_report.htm.

Tol, R.S.J., 2005. The marginal damage costs of carbon dioxide emissions: an assessment of the uncertainties. Energy Policy 33, 2064-2074.

Tubiello, F.N., Cerilli, S., Conchedda, G., 2017. Mapping IPCC greenhouse gas emissions categories to ISIC A in the SEEA AFF. $23^{\text {rd }}$ London Group Meeting on Environmental Accounting. https://seea.un.org/sites/seea.un.org/files/lg23 seea aff ghg final.pdf.

UN, 1992. United Nations Framework Convention on Climate Change. http://unfccc.int/ essential_background/convention/background/items/2853.php.

UN, 2011. United Nations Framework Convention on Climate Change, Conference of the Parties $7^{\text {th }}$ Session, Durban. https://unfccc.int/resource/docs/2011/cmp7/eng/ 10a01.pdf.

UN, 2015. United Nations Framework Convention on Climate Change, Conference of the Parties $21^{\text {st }}$ Session. Adoption of the Paris Agreement. https://unfccc.int/resource/ docs/2015/cop21/eng/109r01.pdf.

UN, 2017. United Nations Framework Convention on Climate Change, Conference of the Parties $23^{\text {rd }}$ Session, Bonn. Achieving the Sustainable Development Goals Through Climate Action. https://cop23.unfccc.int/achieving-the-sustainable-development- 
goals-through-climate-action.

UN, 2018. Ad Hoc Working Group on the Paris Agreement. APA 1.6 Informal.1.Add.1, Bangkok September 2018. https://unfccc.int/sites/default/files/resource/APA1.6. Informal.1.Add_.1.pdf.

UN, et al., 2014a. United Nations, European Commission, Food and Agricultural Organization, Organisation for Economic Co-Operation and Development, World Bank. System of Environmental-Economic Accounting 2012: Central Framework, New York. http://unstats.un.org/unsd/envaccounting/seeaRev/SEEA_CF_Final_en. pdf.

UN, et al., 2014b. United Nations, European Commission, Organisation for Economic CoOperation and Development, World Bank. System of Environmental-Economic Accounting 2012: Experimental Ecosystem Accounting, New York. http://unstats.un. org/unsd/envaccounting/seeaRev/eea_final_en.pdf.

UNDP, 2015. United Nations Development Programme. Sustainable Development Goals. http://www.undp.org/content/undp/en/home/sdgoverview/post-2015development-agenda.html.

UNEP, 2017. United National Environment Programme. SEEA Experimental Ecosystem Accounting: Technical Recommendations. Consultation Draft V4.1: 6 March 2017. UNEP, UNSD, CBD. https://unstats.un.org/unsd/envaccounting/eea_project/TR
consultation/SEEA_EEA_Tech_Rec_Consultation_Draft_II_v4.1_March2017.pdf.

UN-REDD, 2017. United Nations Programme on Reducing Emissions from Deforestation and Degradation. Food and Agriculture Organisation, United Nations Development Programme, United Nations Environment Programme. http://www.un-redd.org/.

UNSD, 2016. United Nations Statistics Division. $11^{\text {th }}$ Meeting UN Committee of Experts on Environmental Economic Accounting. Paper BK/4a(1) Global Assessment of Environmental-Economic Accounting and Supporting Statistics 2014. . https:// unstats.un.org/unsd/envaccounting/ceea/meetings/eleventh_meeting/BK-11-4a-1 report.pdf.

Vardon, M., Burnett, P., Dovers, S., 2016. The accounting push and pull: balancing environment and economic decisions. Ecol. Econ. 124, 145-155.

Vardon, M., Bass, S., Ahlroth, S., Ruijs, A., 2017. Forum on Natural Capital Accounting for Better Policy Decisions: Taking Stock and Moving Forward. World Bank WAVES, Washington DC, USA. https://www.wavespartnership.org/en/knowledge-center/ forum-natural-capital-accounting-better-policy-decisions-taking-stock-and-moving.

Vetrella, G., Femia, A., Tubiello, F.N., 2017. Completing the links between accounts. An application to the Italian case. $23^{\text {rd }}$ London Group Meeting on Environmental Accounting. https://seea.un.org/sites/seea.un.org/files/lg23_seea_aff_ghg_italy_ paper 2017 10 11.pdf. 